\title{
A STUDY OF GROUNDWATER CHARACTERISTICS BY USING OF GROUNDWATER QUALITY INDEX AND POLLUTION INDEX IN ZUBAIR DISTRICT, BASRA PROVINCE, IRAQ
}

\author{
Ammar S. Dawood ${ }^{a}$ *, Mushtak T. Jabbar ${ }^{\text {b }}{ }^{\text {, Mudhar H. Gatea }}{ }^{\text {a }}$, Hayfaa J. Al-Tameemi ${ }^{\text {c }}$ \\ ${ }^{a}$ Civil Engineering Department, College of Engineering, University of Basrah, Basra, Iraq \\ ${ }^{\mathrm{b}}$ Geology /Earth Sciences/ HCC/ Seattle, Washington, 98198, USA \\ ${ }^{c}$ Department of Soil Science and Water Resources, University of Basrah, Basra, Iraq
}

Received: 20.03.2018 / Accepted: 28.04.2018 / Revised: 18.05.2018 / Available online: 31.05.2018

DOI: 10.2478/jaes-2018-0003

KEY WORDS: Groundwater Quality Index, Pollution index, Principal Component Analysis, Cluster Analysis, Zubair.

\begin{abstract}
:
The present work evaluated the groundwater quality index (GWQI) depending on some physicochemical analyses of thirteen groundwater samples in the Zubair district in Basra Province, Iraq. The collected groundwater samples were subjected to an extensive physicochemical analysis to evaluate the characteristics of water for drinking purpose according to Iraqi standard. For calculating the (GWQI), twelve water quality parameters were considered; turbidity, $\mathrm{pH}$, chloride, total dissolved solids, total hardness (TH), electrical conductivity (EC), sodium, sulphate, phosphate, calcium, nitrate, and magnesium. The analysis of the results reveals that all the samples surpassed the portability of drinking water limits. High values of the (GWQI) in the obtained groundwater samples could possibly be caused by the higher values of electrical conductivity, total hardness, chloride, total dissolved solids and sodium within the groundwater. The calculated GWQI values ranged from 73.36 to 595.92. The pollution index (PI) was calculated for the study area with values ranged from 2.97 to 8.26. Correlation coefficients amongst the chosen water parameters exhibited some strong relationships. Finally, the analysis shows that the groundwater in this particular area needs to be treated before its consumption, and in addition, it usually needs to avoid the hazard of contamination. Principal component analysis (PCA) and cluster analysis (CA) indicate that the acquiring-data from groundwater samples are explained $90.5 \%$ of the variance in the data with a four-component system that explains a large portion of the total variance of collected data.
\end{abstract}

\section{INTRODUCTION}

In all over the world, groundwater is used for many purposes including irrigation, domestic, moreover industrial uses. The pollution has acquired increasing in the last few decades due to the continuous-increment in population. There is an increase that is significant to the demand of the fresh water as a result of the rapid development in population and the expanded rate of progress in industrialization. Decreasing in water quality happens to be a worldwide issue of focus since human populations increase, agricultural and industrial activities enlarge, additionally climate change that jeopardizes to influence major changes to the hydrological-cycle (Federation and APHA, 2002). Relating to the WHO organization (WHO, 2004), nearly $80 \%$ of all the people's diseases are caused by water. Hence the quality of water must be expressed in the most common form to analyze the water characteristics.

Whenever groundwater is contaminated or degraded, its quality fails to recover by preventing the contaminants through the source. The guidelines and standards for drinking water quality are planned to admit thoroughly clean and protected water distribution for human consumption, afterward protecting people's wellness. For that reason, it is a necessity to continuously monitor the groundwater quality and to protect it. The general target of any assessment for groundwater quality is often to get an all-inclusive description of the spatial distribution of the quality of groundwater and evaluate the changes in time that occur in the groundwater quality, either in a natural way or under the man's need (Tiwari and Nayak, 2002).

Water quality index (WQI) is the most considerable tool that is effective in conveying information about water quality towards the concerned citizens along with policy-makers. It really is a strategy which is efficient in determining the water characteristics (Singh 1992, Naik et al. 2001, Mishra et al. 2001). Water quality index, therefore, becomes a crucial parameter used in the management and assessment of groundwater. It can help in classifying groundwater: whether or not it is fit for drinking. WQI is computed from the standpoint

\footnotetext{
* Corresponding authors: Ammar S. Dawood, e-mail: ammars.dawood@yahoo.com; Mushtak T. Jabbar, e-mail: mushtak1967@yahoo.com
} 
of that groundwater suitability for man's consumption. WQI is distinctive as a score that reflects the composite-effect of a variety of water quality parameters. The calculation of the WQI in the groundwater study is started at the beginning with Horton (1965) and Landwehr (1974). Wu et al. (2011) reported that the picking of water quality parameters necessity evaluating of the primary anthropogenic-activity in the monitoring location. The primary anthropogenic activity may be domestic, agriculture, mining, etc. It is possible to determine the groundwater quality index (GWQI) by analyzing several important parameters and assign a proper weight for each one.

The aims of the current research are to assess the ground sources of water in the district of Zubair, as drinking water, by identifying the groundwater quality index and examine its suitability for man's consumption. The current work determines the levels of groundwater quality parameters depending on thirteen groundwater samples. Additionally, this research compares the determined levels with the Iraqi standard for drinking. Furthermore, the variability of parameters of the groundwater quality is explored in this paper by using multivariate statistical methods.

\section{MATERIALS AND METHODS}

\subsection{Study area}

The location of the study area is located in the Zubair district in the southern part of Basra Province, Iraq (Figure 1), between longitude $30.1672^{\circ} \mathrm{N}, 46.9805^{\circ} \mathrm{E}$. In the year of 2008 , Zubair district had a population of approximately 240,000 people (Wikipedia, 2017).

\subsection{Data collection and sample analyses}

Groundwater samples examined in this study were obtained from thirteen wells during 2014 by Department of Environmental Protection and Improvement in the Southern Region. The protocol of sampling process is done according to the internationally acceptable standards (Federation and APHA, 2002). Firstly, the physical parameters of water quality had been measured in situ for each sampling location. Secondly, the chemical parameters of water quality had been measured and assessed in the laboratory of the Department of Environmental Protection and Improvement in the Southern Region.

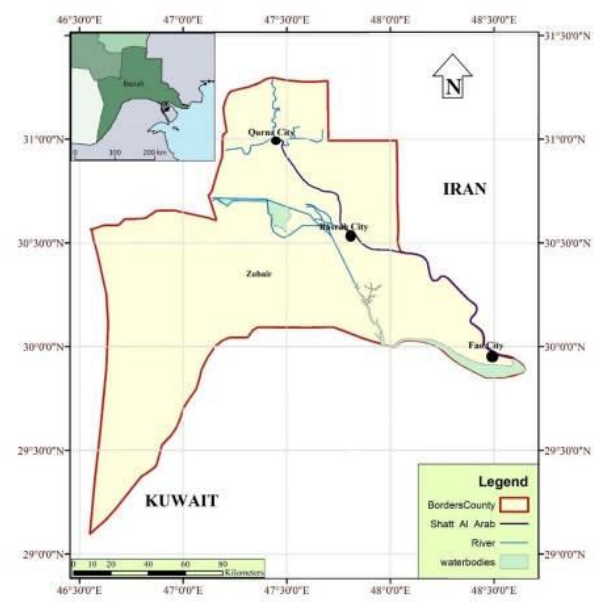

Figure 1. Basra Province map with Zubair district
The analysis of elements and parameters in the laboratory followed the standard methods. Each water-sample from the collected samples was assessed for eleven parameters such as turbidity, $\mathrm{pH}$, chloride, sulphate, sodium, electrical conductivity, total hardness, total dissolved solids, magnesium, calcium, nitrate, and phosphate using standard-procedures of water test advised by the Federation and APHA (2002). The map for distribution of groundwater samples in the area of the study is displayed in Figure 2.

\subsection{Data analysis}

Descriptive-statistics of the parameters used for groundwater quality were carried out by implementing MS-Excel software version 2013 and making use of SPSS software version 20. The elements of descriptive-statistics for groundwater samples that result included mean, minimum, maximum, range, and standard deviation. Descriptive-statistics for the studied parameters for water quality of various sampling locations are introduced in Table 1.

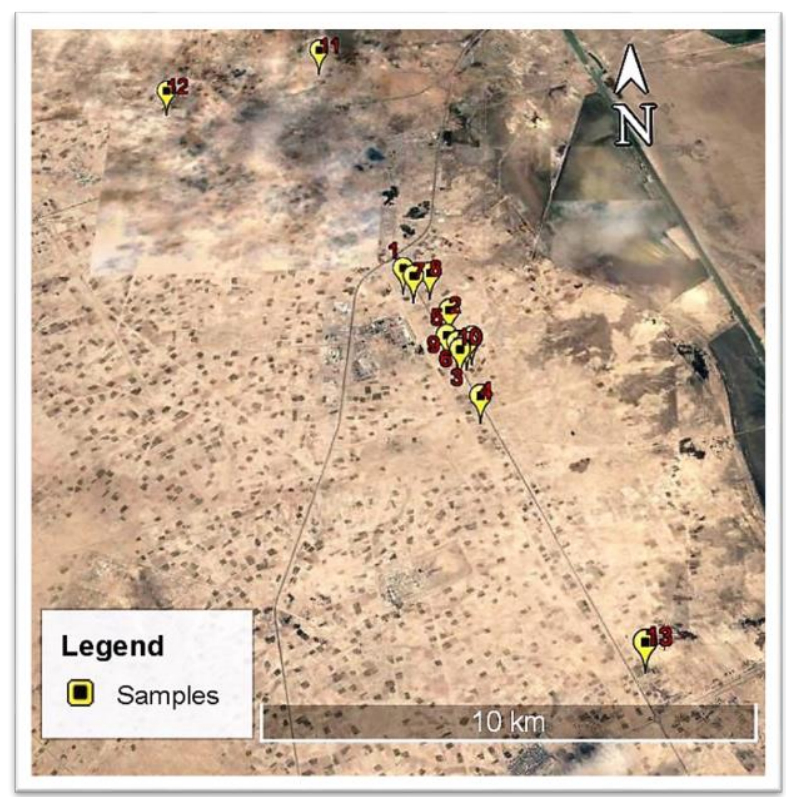

Figure 2. Location of groundwater samples in the area of the study in Zubair district

Table 1. Descriptive statistics of groundwater samples in the study area

\begin{tabular}{llllll}
\hline Parameter & Mean & Min. & Max. & Range & Std.Dev \\
\hline Turbidity & 2.169 & 0.040 & 8.66 & 8.62 & 2.607 \\
pH & 7.292 & 7.000 & 7.60 & 0.6 & 0.189 \\
Electrical Conductivity & 8860.0 & 6010.0 & 15750.0 & 9740 & 2452.5 \\
Total Dissolved Solids & 6661.5 & 4420.0 & 13000.0 & 8580 & 2156.8 \\
Chloride & 1980.9 & 1140.0 & 4750.0 & 3610 & 948.8 \\
Sulphate & 1423.1 & 900.0 & 2000.0 & 1100 & 292.7 \\
Sodium & 1796.6 & 1100.0 & 4500.0 & 3400 & 905.9 \\
Total Hardness & 2571.1 & 1680.0 & 5600.0 & 3920 & 1099.4 \\
Magnesium & 245.8 & 132.0 & 579.00 & 447 & 140.6 \\
Calcium & 617.2 & 432.0 & 1280.00 & 848 & 216.9 \\
Nitrate & 35.7 & 0.156 & 53.79 & 53.6 & 18.263 \\
Phosphate & 0.65 & 0.310 & 2.68 & 2.37 & 0.640 \\
\hline
\end{tabular}




\subsection{Physicochemical parameters}

The turbidity of the water is the haziness associated with the water as a result of the suspended individual particles. There are different sizes of suspended solid matter in the groundwater. The particles can effortlessly settle-down in water, meanwhile, the suspended solids remain in suspension and it appears as turbid water because it is not enough weight to get settled up.

The measure of the activity for hydrogen ion in water solution is referred to as $\mathrm{pH}$. In pure water and at a temperature equal to $25^{\circ} \mathrm{C}$, the $\mathrm{pH}$ value close to 7 . When the $\mathrm{pH}$ of solutions is less than 7 , these types of solutions are generally referring to acidic solutions, but when the $\mathrm{pH}$ value of the solution is much larger than 7 , it is classified as alkaline or basic solutions. WHO guidelines for drinking water quality state that the direct exposure, severe $\mathrm{pH}$ (on low or high $\mathrm{pH}$ values) effects of irritability to the eyes, mucous membrane, and skin of human beings.

Electrical conductivity is commonly applied as an index of the salt level and ion-contents contained in water. The features of pure-water are lower-conductivity and higher-resistivity. The number of inorganic substances that are obtained as the dissolved form is regarded as the total dissolved solids. The sizes of these inorganic substances (dissolved substances) tend to be even significantly lower than two micrometers and should not be identified in sieve tests.

In nature, chlorine is not present in free form and it most generally may appear as sodium chloride. The compounds of the chlorine are very soluble in water and therefore the groundwater gains chlorides by dissolving them in it. The compounds of the sodium are frequently found in the soil and rocks as a significant percentage. These compounds are dissolving in the groundwater by flow through the soil and rocks. One of the key elements for saltwater intrusion is the rise of sodium concentration in the groundwater. Other ions in water, such as sulfate, magnesium, calcium, nitrate, and phosphate, are also a significant component of groundwater which usually needed for drinking nonetheless in small amounts.

The water-hardness results from the existence of magnesium and calcium compounds along with other several minerals. Water is a good-solvent and efficiently dissolves the minerals that can come in contact. In water, the dissolved magnesium and calcium are majority typical minerals that make hardness of water.

\subsection{Calculation of GWQI}

Groundwater quality index (GWQI) is calculated in accordance with the following equation.

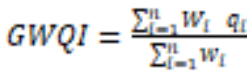

where,

$W_{n}$ is express the unit weight of the $\mathrm{i}^{\text {th }}$ water quality parameter. $q_{n}$ is express the quality rating of the $i^{\text {th }}$ water quality parameter.

The unit weight $\left(w_{n}\right)$ of the $i^{\text {th }}$ water quality parameter is computed in the subsequent equation and it is inversely correspondent with the advised standards for the related parameters.

$$
W_{i}=\frac{K}{s_{i}}
$$

where,

$K$ is express a constant-proportionality and it can be derived as in equation 3.

$S_{i}$ is express the standard-value of the $i^{\text {th }}$ water quality parameter.

$$
k=\frac{1}{\sum \sum_{i=1}=1\left(W_{0}\right)}
$$

The quality rating is calculated according to the following equation

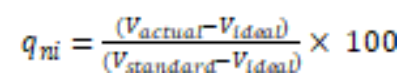

where,

$q_{n i}$ is the quality rating of the $i^{\text {th }}$ parameter for the total (n) number of the water quality parameters.

$V_{\text {actual }}$ is the measured-value of water quality parameter (find from the laboratory).

$V_{\text {ideal }}$ is the standard-value of water quality parameter (find from standard tables).

The value of $V_{\text {ideal }}$ for $\mathrm{pH}$ is 7 and for the other studied water quality parameters is zero. Table 2, shows the water quality category depending on the computed value of GWQI.

Table 2. Water quality classification based on the computed value of WQI (Rupal et al, 2012)

\begin{tabular}{lll}
\hline Water Class & GWQI value & The status of water quality \\
\hline I & $<50$ & Excellent \\
II & $50-100$ & Good water \\
III & $100-200$ & Poor water \\
IV & $200-300$ & Very poor water \\
V & $>300$ & Unsuitable water for drinking \\
\hline
\end{tabular}

\subsection{Calculation of Pollution index (PI)}

The pollution index refers to the Nemerow pollution index, that is the method of calculation the pollution which prepared by Nemerow and Sumitomo in early 1970. Both of Ming et al. (2010) and Wu et al (2010) have studied this index. The simple form of the pollution index and it is specified as:

$$
P I_{i}=\frac{C_{i}}{s_{i}}
$$

where,

$\mathrm{C}_{\mathrm{i}}$ is the measured-value of the $\mathrm{i}^{\text {th }}$ water quality parameter.

$\mathrm{S}_{\mathrm{i}}$ is the standard-value of the $\mathrm{i}^{\text {th }}$ water quality parameter.

The average of pollution index $\left(\mathrm{PI}_{\text {avg }}\right)$ is defined as

$$
P I_{\text {avg }}=\frac{1}{n} \sum_{i=1}^{n} P I_{i}
$$

The perfect value of the $\mathrm{PI}_{\text {avg }}$ must be less than or equal to 1 . There are four types of classification for the pollution-level which is dependent on water quality standard and it is represented in table 3 .

Table 3. Level of pollution depending on water standard quality (Al-Othman, 2015)

\begin{tabular}{cll}
\hline Class of Water & \multicolumn{1}{c}{$\mathrm{PI}_{\mathrm{avg}}$ value } & The status of pollution level \\
\hline I & $0<\mathrm{PI}_{\text {avg }}<1$ & Good water \\
\hline II & $1<\mathrm{PI}_{\text {avg }}<5$ & Slight polluted water \\
\hline III & $5<\mathrm{PI}_{\text {avg }}<10$ & Medium pollution of water \\
\hline IV & $\mathrm{PI}_{\text {avg }}>10$ & Heavily polluted water \\
\hline
\end{tabular}




\subsection{Correlation, PCA, and CA}

The correlation is the research associated with the relationship between any two or more functionally variables. In waterquality studies, the analysis of correlations can be used to determine the forte and statistical significance of the relationship between any two or some other random water quality variables. The strength of the relationship between two random variables can be identified throughout the computation of correlation coefficient (R). When the value of $r$ is close to zero, this means the poorer the correlation. The value of $(\mathrm{R})$ ranges from -1 to 1 . But when the value of $(\mathrm{R})$ is close to -1 , it implies that there is a strong negative correlation between the two random variables. But when the value of $(R)$ is close to 1 , it reveals that there is a strong positive correlation the two random variables, both variables decrease and increase with each other. The principal component analysis (PCA), cluster analysis (CA), and the correlation coefficient analysis (CCA), were used to determine the potential sources of the groundwater parameters.

\section{RESULTS AND DISCUSSION}

\subsection{Results of physicochemical parameters}

The Iraqi standard guideline for using water for drinking purposes and its related unit weights assigned are demonstrated in Table 3. From comparing the physiochemical results of the groundwater samples and its corresponding maximum values as recommended by the Iraqi standards that are shown in Table 1. It is noticeable that $38.5 \%$ of the groundwater samples didn't abide by the Iraqi standards for $\mathrm{NO}_{3}$; moreover, almost all the samples were not confirmed to the recommended EC, TDS, $\mathrm{SO}_{4}, \mathrm{Na}, \mathrm{TH}, \mathrm{Mg}$, and $\mathrm{Ca}$ limits. Furthermore, all of the samples met the requirement for $\mathrm{pH}$. Furthermore, $40 \%$ of groundwater samples were not compliant with the recommended $\mathrm{PO}_{4}$. Mean levels of $\mathrm{EC}, \mathrm{TDS}, \mathrm{Cl}, \mathrm{SO}_{4}, \mathrm{Na}, \mathrm{TH}$, $\mathrm{Mg}, \mathrm{Ca}$ and $\mathrm{PO}_{4}$ were over the allowable levels of Iraqi standard for drinking water; obviously demonstrating the anthropogenic effect.

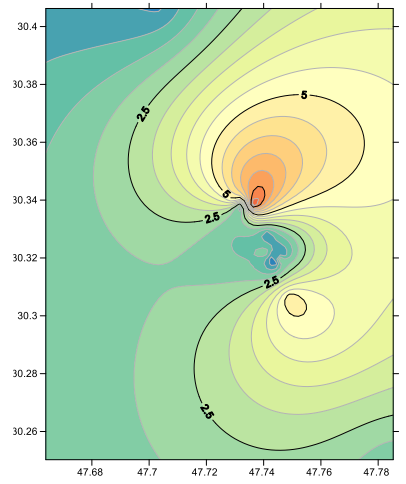

(a)

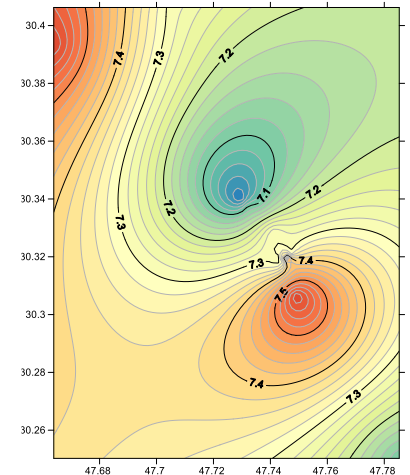

(b)

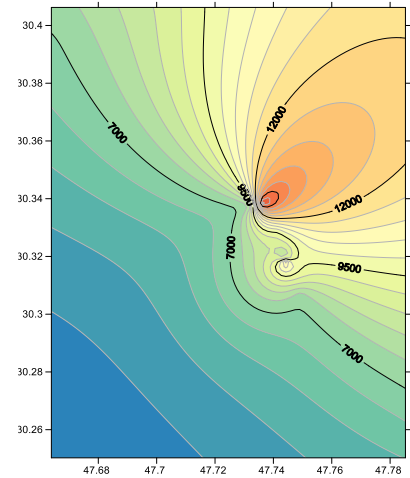

(c)

Figure 3. Spatial distribution map for (a) turbidity, (b) $\mathrm{pH}$, and

(c) electrical conductivity in the study area

The summary of analyzed-parameters result from this study-area is tabulated and presented in table 1 and Figs. 3-6, respectively. In study-area, it is noticed that the $\mathrm{pH}$ of samples lies within the allowable limit state by the Iraqi standard (6.5-8.5) with the average value of 7.292 (Table 1 and Figure 3.a). The value of turbidity in the study-area is ranged between 0.04 NTU to 8.66 NTU with the average value of 2.169 NTU (Table 1 and Figure 3.b). It is noticed from the results of the study-area that the electrical conductivity ranged between $6010 \mu \mathrm{S} / \mathrm{cm}$ to 15750 $\mu \mathrm{S} / \mathrm{cm}$ with an average of $8860 \mu \mathrm{S} / \mathrm{cm}$ (Table 1 and Figure 3.c). In the study-area, TDS values ranged between $1950-3150 \mathrm{mg} / \mathrm{L}$ with an average of $2269.7 \mathrm{mg} / \mathrm{L}$ (Table 1 and Figure 4.a). In groundwater, when the total dissolved solids have high value, it may be not harmful to people, but it has an effect on the persons who are suffering from heart diseases and kidney. The chloride concentration is high in groundwater, whenever rainfall is less and the temperature is high. The chloride content in the area of the study was revealed to be more than the allowable levels. The chloride ranges between $1140-4750 \mathrm{mg} / \mathrm{L}$ with an average value of $1980.92 \mathrm{mg} / \mathrm{L}$ (Table 1 and Figure 4.b). The permissible value of sulphate for drinking water is $400 \mathrm{mg} / \mathrm{L}$. It is presented with the results of the area of the study that the concentration of sulphate ranged between $900-2000 \mathrm{mg} / \mathrm{L}$ with an average of $1423.077 \mathrm{mg} / \mathrm{L}$ (Table 1 and Figure 4.c). It is proven that all the groundwater samples of the study area exceed the permissible value of sulphate in drinking water recommended by the Iraqi standard.

Table 4. Iraqi standard guideline for drinking water and its corresponding unit weights (Hadeel, 2014)

\begin{tabular}{lcc}
\hline Parameter & Standard value & Assigned unit weight \\
\hline Tur. & 5 & 0.2000 \\
$\mathrm{pH}$ & 8.5 & 0.1176 \\
$\mathrm{EC}$ & 1000 & 0.0010 \\
$\mathrm{TDS}$ & 1000 & 0.0010 \\
$\mathrm{Cl}$ & 350 & 0.0029 \\
(c) $\mathrm{SO}_{4}$ & 400 & 0.0025 \\
$\mathrm{Na}$ & 200 & 0.0050 \\
$\mathrm{TH}$ & 500 & 0.0020 \\
$\mathrm{Mg}$ & 100 & 0.0100 \\
$\mathrm{Ca}$ & 150 & 0.0067 \\
$\mathrm{NO}_{3}$ & 50 & 0.0200 \\
$\mathrm{PO}_{4}$ & 0.4 & 2.5000 \\
\hline
\end{tabular}




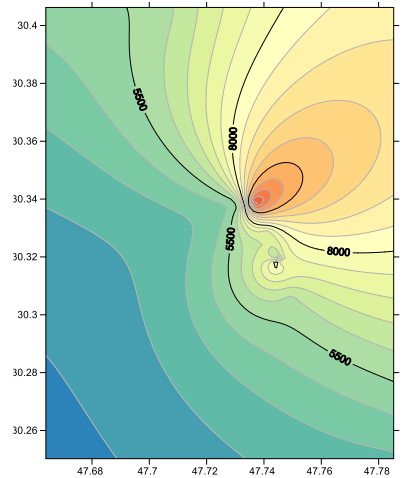

(a)

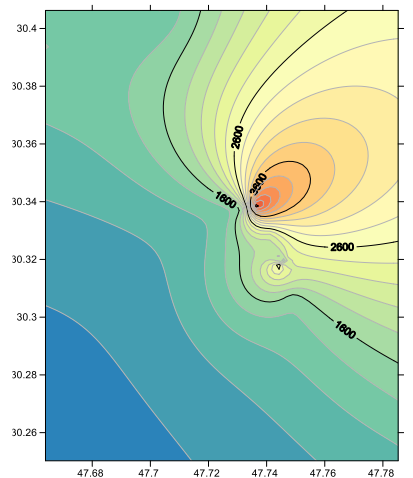

(b)

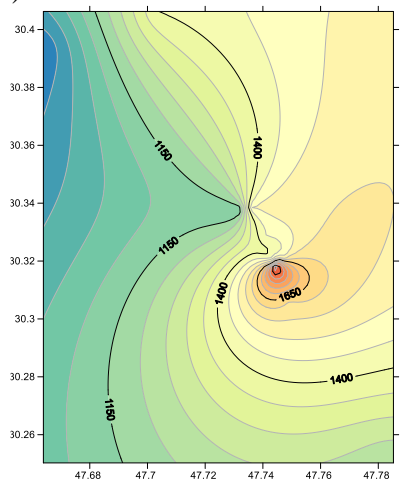

(c)

Figure 4. Spatial distribution map for (a) total dissolved solids, (b) chloride, and (c) sulphate in the study area

It is found from the analysis of the results that all the groundwater samples have a sodium-content more than the maximum limit of $200 \mathrm{mg} / \mathrm{L}$ depending on the Iraqi standard for drinking water. The range of sodium levels in the area of the study is $110-4500 \mathrm{mg} / \mathrm{L}$ (Table 1 and Figure 5.a). The hardness of water shows that it ranged between $1680 \mathrm{mg} / \mathrm{L}$ to $5600 \mathrm{mg} / \mathrm{L}$ (Table 1 and Figure 5.b). In the area of the study, the concentration of magnesium ranged between 132-579 $\mathrm{mg} / \mathrm{L}$ with an average of $245.84 \mathrm{mg} / \mathrm{L}$ (Table 1 and Figure 5.c). The range of magnesium values in the area of the study is not permissible.

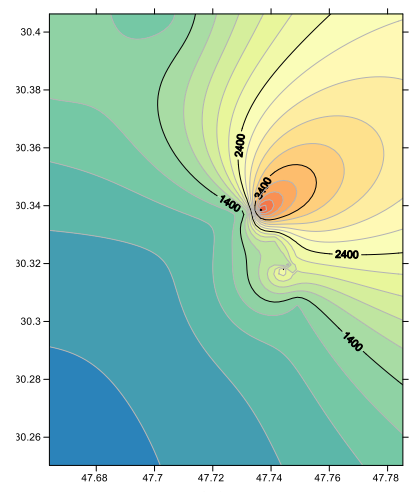

(a)

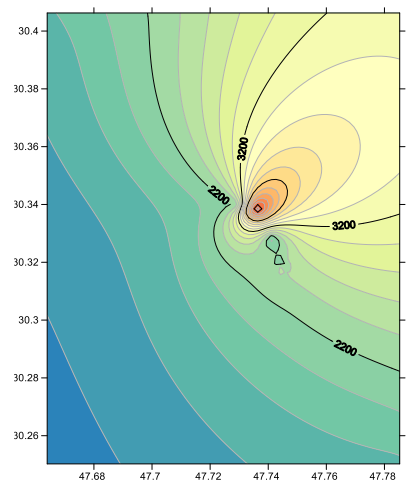

(b)

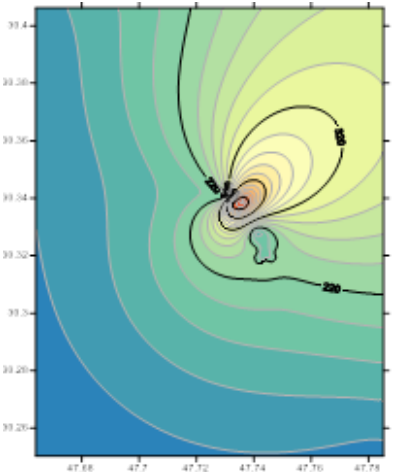

(c)

Figure 5. Spatial distribution map for (a) sodium, (b) total hardness, and (c) magnesium in the study area

The calcium content in groundwater samples of the area of the study ranged between $432-1280 \mathrm{mg} / \mathrm{L}$ with an average of $617.23 \mathrm{mg} / \mathrm{L}$ (Table 1 and Figure 6.a). The range of calcium values in the area of the study is not permissible because its values were exceeded the permissible value of calcium in drinking water recommended by the Iraqi standard. In studyarea, the nitrate value varied from $0.156 \mathrm{mg} / \mathrm{L}$ to $53.79 \mathrm{mg} / \mathrm{L}$ (Table 1 and Figure 6.b). The value of nitrate content in the study area was found to be more than the value of $50 \mathrm{mg} / \mathrm{L}$ as per Iraqi standard in 6 locations. The high value of nitrate concentration is located in the rural part of the study area as a result of the over-use of fertilizer and the improper-operation as well as the maintenance of septic systems. The phosphate content ranges between $0.31-2.68 \mathrm{mg} / \mathrm{L}$ with an average value of $0.655 \mathrm{mg} / \mathrm{L}$ (Table 1 and Figure 6.c).

\subsection{Results of GWQI calculations}

The value of GWQI demonstrates its appropriateness for human-drinking. In this research, the calculated GWQI values ranged from 73.363 to 595.9186 and which means that the GWQI can be classified into three types as shown in Table 4 and Figure 7. The higher GWQI value means the most polluted in groundwater. The higher value of GWQI in these locations of the study-area has found from the higher-values of total hardness, nitrate, total dissolved solids, and also manganese in the groundwater-samples. Table 5 shows the GWQI of watersamples.

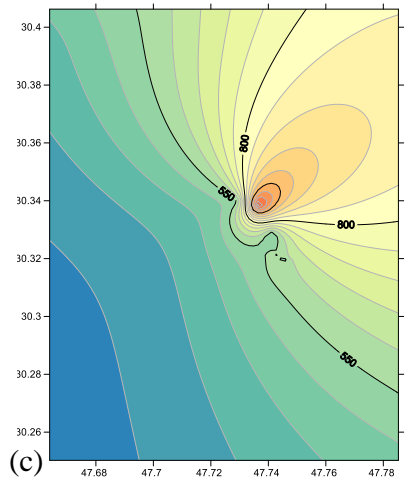

(a)

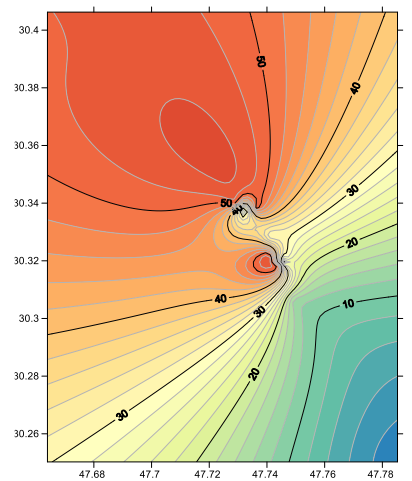

(b) 


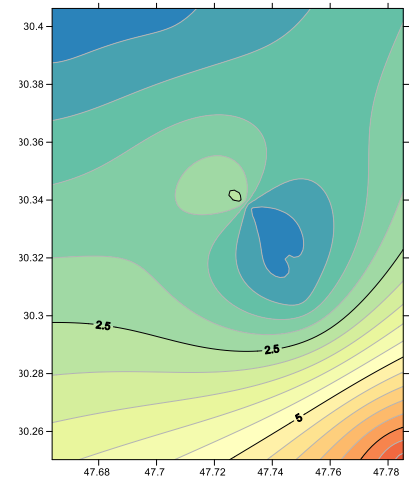

(c)

Figure 6. Spatial distribution map for (a) calcium, (b) nitrate, and (c) phosphate in the study area

Table 5. GWQI and PI values of the groundwater samples

\begin{tabular}{|c|c|c|c|c|c|c|}
\hline Well & 1 & 2 & 3 & 4 & 5 & 6 \\
\hline GWQI & 595.9 & 87.3 & 185.5 & 172.6 & 91.9 & 83.7 \\
\hline PI & 4.04 & 3.83 & 3.68 & 3.48 & 3.89 & 4.23 \\
\hline Well & 7 & 8 & 9 & $\begin{array}{ll}10 & 11\end{array}$ & 12 & 13 \\
\hline GWQI & 112.5 & 146.5 & 75.4 & $\begin{array}{ll}73.4 & 75.9\end{array}$ & 83.5 & 195.4 \\
\hline PI & 4.19 & 8.26 & 4.94 & $3.53 \quad 3.33$ & 2.97 & 2.80 \\
\hline
\end{tabular}

From Table 4 and Figure 7, the groundwater samples from all sampling locations had only one GWQI greater than 300 and can, for this reason, be regarded as unsuitable for drinking without previous treatment. The electrical conductivity, total dissolved salt and other ions of the groundwater samples are mainly the reason for the higher GWQI values. Approximately $54 \%$ of groundwater samples had GWQI values with the type of good water. Around $38 \%$ of groundwater samples had GWQI values with the poor water type.

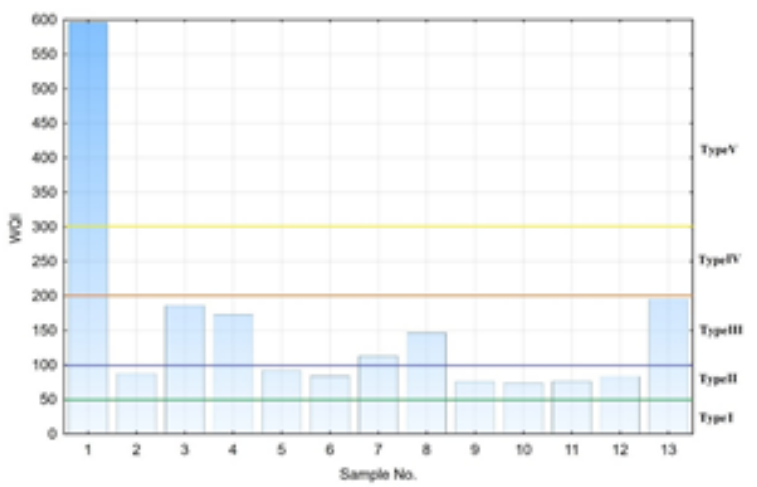

Figure 7. GWQI values for the groundwater samples in the area of the study

\subsection{Results of pollution index}

The average pollution index $\left(\mathrm{PI}_{\text {avg }}\right)$ values range from 2.97 to 8.26. From the results of $\mathrm{PI}_{\mathrm{avg}}$ for the selected groundwater samples (Table 4), depending on $\mathrm{PI}_{\mathrm{avg}}, 8 \%$ of the groundwater samples indicate medium polluted water and $92 \%$ of the groundwater samples have slightly polluted water (Figure 8). Figure 8 displays the variation of $\mathrm{PI}_{\mathrm{avg}}$ at various locations of the study area.

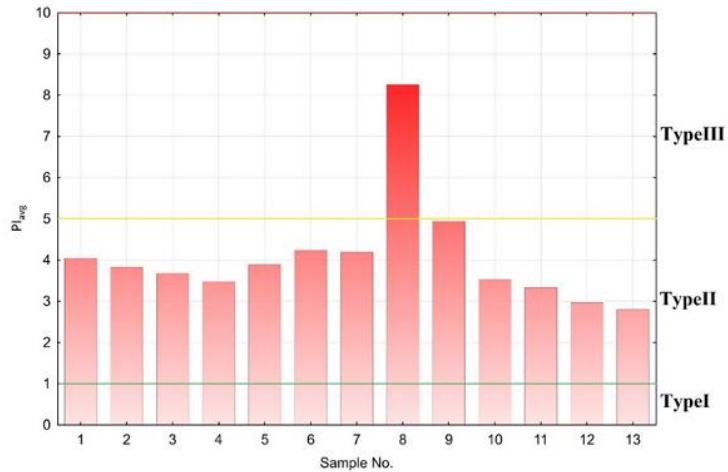

Figure 8. $\mathrm{PI}_{\text {avg }}$ values for the groundwater samples in the area of the study

\subsection{Results of statistical analysis}

Figure 9, shows the scatter plot that denotes the data is of a multi-component scheme and this really is revealed by Table 5 as four components cumulatively explained about $90.5 \%$ of the variance in the collected data. From Table 5, exclusively components 1 to 4 has Eigenvalues which are greater than 1 .

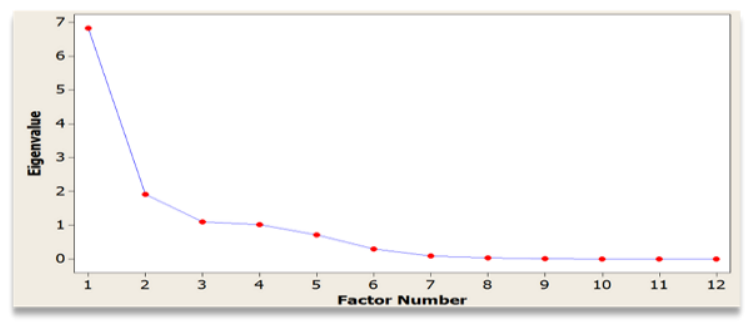

Figure 9. Scatter plot of Eigenvalues for the groundwater samples

From the Principal Component Matrix (Table 6), the representation for each PCs can be written as follow:

$\mathrm{PC} 1=0.642$ Tur $-0.398 \mathrm{pH}+0.931 \mathrm{EC}+0.966 \mathrm{TDS}+0.957$ $\mathrm{Cl}+0.246 \mathrm{SO}_{4}+0.957 \mathrm{Na}+0.911 \mathrm{TH}+0.830 \mathrm{Mg}+0.957 \mathrm{Ca}+$ $0.349 \mathrm{NO}_{3}-0.066 \mathrm{PO}_{4}$

$\mathrm{PC} 2=0.385$ Tur $-0.642 \mathrm{pH}-0.265 \mathrm{EC}-0.222 \mathrm{TDS}-0.162 \mathrm{Cl}$ $-0.684 \mathrm{SO}_{4}-0.145 \mathrm{Na}+0.199 \mathrm{TH}+0.249 \mathrm{Mg}+0.135 \mathrm{Ca}-$ $0.132 \mathrm{NO}_{3}+0.765 \mathrm{PO}_{4}$

$\mathrm{PC} 3=-0.150$ Tur $+0.060 \mathrm{pH}-0.182 \mathrm{EC}-0.094$ TDS -0.116 $\mathrm{Cl}-0.162 \mathrm{SO}_{4}-0.102 \mathrm{Na}+0.315 \mathrm{TH}+0.396 \mathrm{Mg}+0.212 \mathrm{Ca}-$ $0.642 \mathrm{NO}_{3}-0.512 \mathrm{PO}_{4}$

PC4 $=-0.467$ Tur $-0.176 \mathrm{pH}-0.016 \mathrm{EC}-0.039$ TDS -0.017 $\mathrm{Cl}-0.503 \mathrm{SO}_{4}+0.005 \mathrm{Na}+0.071 \mathrm{TH}+0.123 \mathrm{Mg}+0.014 \mathrm{Ca}$ $+0.614 \mathrm{NO}_{3}-0.336 \mathrm{PO}_{4}$

The standardization factors were substitution into expressions for the four PCs. The values for PCs 1,2,3 and 4 were discovered by determining each of PCs of water quality individually. Since PCs 3 and 4 are comparatively less than

PCs 1 and 2, accordingly it is more difficult to analyze it in the three-dimensional space, PCs 1 and 2 were selected for the distribution analyze of water quality in this research (see Figure $10)$. 
The cluster analysis was utilized for the identification of the spatial-similarity amongst the sampling sites that depending on the levels of groundwater parameters. All of the thirteen sampling sites are grouped into four statistically significant clusters, as illustrated by the Dendrogram (see Figure 11). A Dendrogram is an important tool in assessing the significant variables and source of pollution. From Figure 10, only two sampling locations are spatially comparable, i.e. cluster 1 (1 and 7), six locations (2, 6, 5, 10, 11 and 9) form the second cluster while the four locations $(3,4,12$ and 13$)$ form the third cluster. Finally, one location for the fourth cluster.

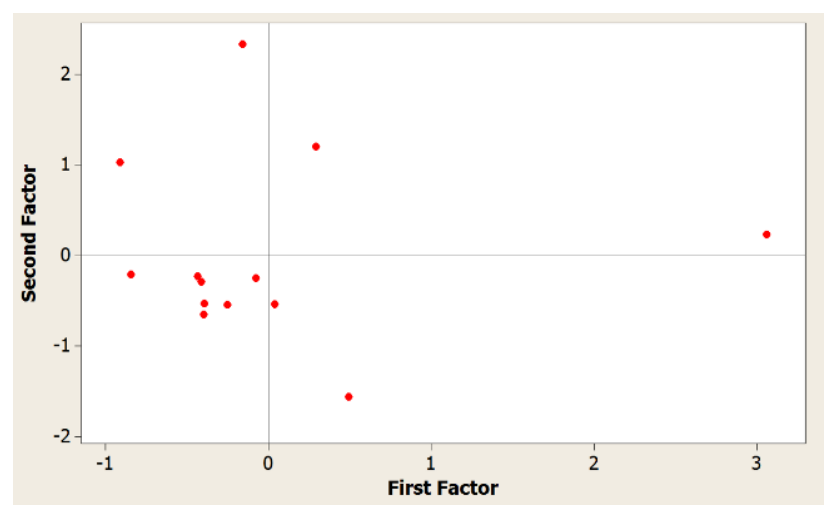

Figure 10. Values of PCs1 and PCs2 for water samples

The coefficients of Pearson correlation between the selected groundwater properties revealed high and strong relationships (see Table 7). It was noticed that there is a high correlation ( $\mathrm{R}>0.9)$ that were observed between the following parameters: (EC with each of TDS, $\mathrm{Cl}$, and $\mathrm{Na}$ ), (TDS with each of $\mathrm{Cl}$ and $\mathrm{Na}),\left(\mathrm{Ca}\right.$ with each of $\mathrm{SO}_{4}$ and $\mathrm{Mg}$ ), and $(\mathrm{Cl}$ and $\mathrm{Na})$. Table 7 also shows a strong relationship $(\mathrm{R}>0.8)$ between the following parameters: (EC and $\mathrm{Ca})$, (TDS and $\mathrm{Ca}),(\mathrm{Cl}$ and $\mathrm{Ca})$, and $(\mathrm{Ca}$ and $\mathrm{Na}$ ).

Table 6. Principal Component Matrix (PCM) of data (groundwater samples)

\begin{tabular}{lllll}
\hline Variable & PCs1 & PCs2 & PCs3 & PCs4 \\
\hline Tur. & 0.642 & 0.385 & -0.150 & -0.467 \\
\hline $\mathrm{pH}$ & -0.398 & -0.642 & 0.060 & -0.176 \\
\hline $\mathrm{EC}$ & 0.931 & -0.265 & -0.182 & -0.016 \\
\hline $\mathrm{TDS}$ & 0.966 & -0.222 & -0.094 & -0.039 \\
\hline $\mathrm{Cl}$ & 0.957 & -0.162 & -0.116 & -0.017 \\
\hline $\mathrm{SO} 4$ & 0.246 & -0.684 & -0.162 & -0.503 \\
\hline $\mathrm{Na}$ & 0.957 & -0.145 & -0.102 & 0.005 \\
\hline $\mathrm{TH}$ & 0.911 & 0.199 & 0.315 & 0.071 \\
\hline $\mathrm{Mg}$ & 0.830 & 0.249 & 0.396 & 0.123 \\
\hline $\mathrm{Ca}$ & 0.957 & 0.135 & 0.212 & 0.014 \\
\hline $\mathrm{NO} 3$ & 0.349 & -0.132 & -0.643 & 0.615 \\
\hline $\mathrm{PO} 4$ & -0.066 & 0.765 & -0.512 & -0.336 \\
\hline Variance & 6.8265 & 1.9175 & 1.0945 & 1.0159 \\
\hline$\%$ Var & 0.569 & 0.160 & 0.091 & 0.085 \\
\hline
\end{tabular}

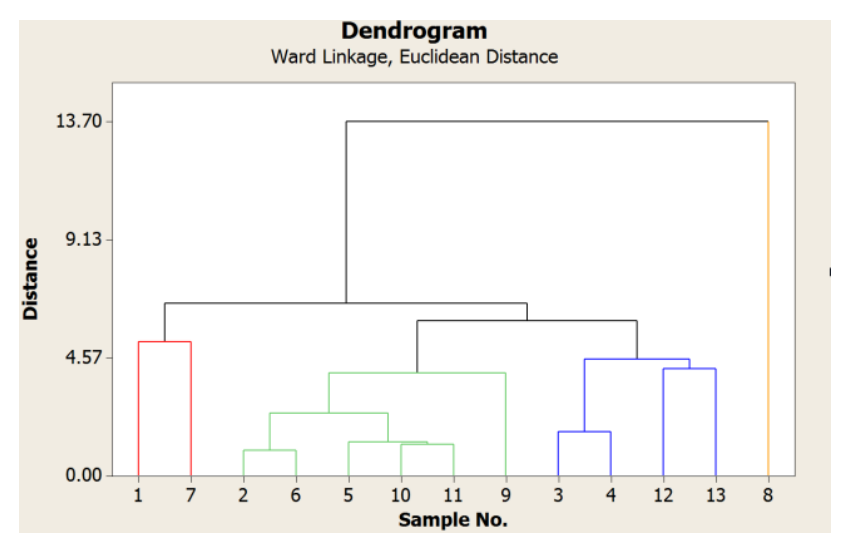

Figure 11. Dendrogram using Ward Linkage (between Groups)

Table 7. Correlation of groundwater quality parameters in the samples of the area of the study

\begin{tabular}{|c|c|c|c|c|c|c|c|c|c|c|c|c|}
\hline Parameter & Turbidity & $\mathrm{pH}$ & EC & TDS & $\mathrm{Cl}$ & $\mathrm{SO}_{4}$ & $\mathrm{Na}$ & $\mathrm{TH}$ & $\mathrm{Mg}$ & $\mathrm{Ca}$ & $\mathrm{NO}_{3}$ & $\mathrm{PO}_{4}$ \\
\hline Turbidity & 1 & & & & & & & & & & & \\
\hline $\mathrm{pH}$ & -.195 & 1 & & & & & & & & & & \\
\hline $\mathrm{EC}$ & .500 & -.248 & 1 & & & & & & & & & \\
\hline TDS & .570 & -.249 & .977 & 1 & & & & & & & & \\
\hline $\mathrm{Cl}$ & .554 & -.309 & .957 & .985 & 1 & & & & & & & \\
\hline $\mathrm{SO}_{4}$ & .008 & .222 & .454 & .405 & .342 & 1 & & & & & & \\
\hline $\mathrm{Na}$ & .559 & -.312 & .952 & .982 & .996 & .299 & 1 & & & & & \\
\hline TH & .592 & -.444 & .728 & .791 & .775 & .027 & .780 & 1 & & & & \\
\hline $\mathrm{Mg}$ & .505 & -.441 & .618 & .686 & .675 & -.040 & .676 & .980 & 1 & & & \\
\hline $\mathrm{Ca}$ & .658 & -.428 & .815 & .869 & .849 & .096 & .858 & .976 & .914 & 1 & & \\
\hline $\mathrm{NO}_{3}$ & .055 & -.089 & .445 & .388 & .377 & -.034 & .376 & .170 & .128 & .210 & 1 & \\
\hline $\mathrm{PO}_{4}$ & .442 & -.437 & -.163 & -.182 & -.127 & -.251 & -.134 & -.076 & -.071 & -.080 & .004 & 1 \\
\hline
\end{tabular}

\section{CONCLUSIONS}

The evaluation study of the groundwater quality index (GWQI) was carried out in Zubair district depending on the physicochemical analyses of thirteen groundwater samples in the study area. The quality of groundwater samples is obtained from the area under investigation that examined and analyzed of twelve parameters, specifically turbidity, $\mathrm{pH}$, electrical conductivity, chloride, sulphate, sodium, total dissolved solids, total hardness, magnesium, calcium, nitrate, and phosphate. Furthermore, the studied parameters were used to obtain the GWQI and the average of PI values. Most groundwater samples exceeded the upper limit of the Iraqi standard for drinking water. GWQI values range from 73.36 to 595.92 and the PIavg values range from 2.97 to 8.26 . The main objective of this research was to formulate a database map for the area of the study and to assess the quality of groundwater in Zubair district. The Pearson correlation coefficients between the selected groundwater properties showed different relationships. Principal component analysis and cluster analysis that were used in this study recommend the data is of a four-component system type which is explained approximately $90.5 \%$ of the total variance in the data used. The study indicates that the groundwater of the study area needs prior treatment before human-consumption such as drinking. 


\section{REFERENCES}

Al-Othman, A.A., 2015. Evaluation of the suitability of surface water from Riyadh mainstream Saudi Arabia for a variety of uses. Arabian Journal of Chemistry, pp. 1-7.

Federation, W.E. and American Public Health Association, 2005. Standard methods for the examination of water and wastewater. American Public Health Association (APHA): Washington, DC, USA.

Hadeel A. A., 2014. Assessment of Water Quality Index for Euphrates River within Babylon Province, Iraq During the Period 2007-2013, International Journal of Civil Engineering and Technology, 5(5), pp. 41-50.

Horton, R.K., 1965. An index number system for rating water quality. Journal of Water Pollution Control Federation, 37(3), pp.300-306.

Landwehr, J.M., Deininger, R.A. and Harkins, R.D., 1974. An objective water quality index. Journal of Water Pollution Control Federation, pp.1804-1809.

Mishra, P.C. and Patel, R.K., 2001. Study of the pollution load in the drinking water of Rairangpur, a small tribal dominated town of North Orissa. Indian J Environ Ecoplan, 5(2), pp.293298

Naik, S. and Purohit, K.M., 2001. Studies on water quality of river Brahmani in Sundargarh district, Orissa. Indian J Environ Ecoplan, 5(2), pp.397-402.

Nemerow, N.L. and Sumitomo, H., 1970. Benefits of water quality enhancement. Report No. 16110 DAJ, prepared for the U.S. Environmental Protection Agency. December 1970. Syracuse University, Syracuse, New York, United States.

Rupal, M., Tanushree, B. and Sukalyan, C., 2012. Quality characterization of groundwater using water quality index in Surat city, Gujarat, India. International Research Journal of Environment Sciences, 1(4), pp.14-23.

Shan, W., Yue-heng, H. and Dan, Z., 2011. Discussion on Parameter Choice for Managing Water Quality of the Drinking Water Source. Procedia Environmental Sciences, 11, pp.14651468.

Singh, D.F., 1992. Studies on the water quality index of some major rivers of Pune, Maharashtra. In Proc Acad Environ Biol, 1(1), pp. 61-66.

Tiwari, T.N. and Nayak, S., 2002. Water Quality Index for the Groundwater of Sambalpur Town. Environmental Pollution Research. New Delhi: APH Pub. Corp, p.971.

Wikipedia, 2017. Az Zubayr, This article is about the city in Iraq. https://en.wikipedia.org/wiki/Az_Zubayr.

World Health Organization, 2004. Guidelines for drinkingwater quality: recommendations (Vol.1). World Health Organization.
Wu, Q., Zhao, C. and Zhang, Y., 2010. Landscape river water quality assessment by nemerow pollution index. International Conference, IEEE. In Mechanic Automation and Control Engineering (MACE), pp. 2117-2120.

Zhu, M., Li, Y., Li, J. and Yang, L., 2010. A Nemerow Index and Vague Sets Integrated Water Quality Comprehensive Assessment Model. 4th International Conference, IEEE In Bioinformatics and Biomedical Engineering (iCBBE), pp. 14.

\section{ACKNOWLEDGEMENTS}

This research was supported by the Engineering College, University of Basrah. The authors are grateful to the anonymous reviewers for their critical review and comments on drafts of this manuscript. 